Diagenetic factors controlling reservoir quality in the Faraghan Formation (Lower Permian), Darang Field, Southern Iran

\author{
by \\ Seyed Mohammad Zamanzadeh, Saeid Mirzaei, Mehrdad Sardar Abadi \\ and Mohammad Poosti
}

reprinted from

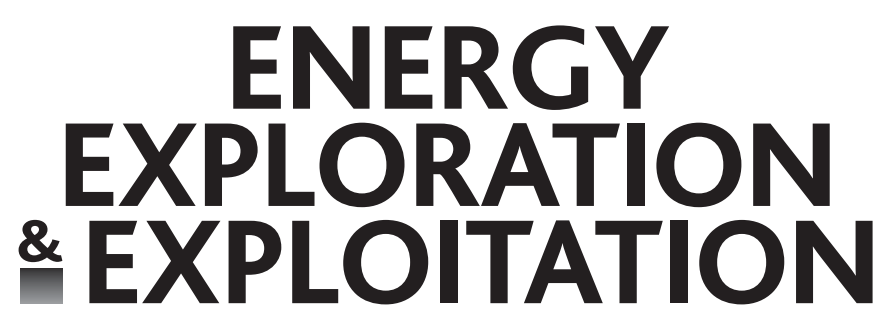

Volume 292011

Number 2

(C) 2011

MULTI-SCIENCE PUBLISHING CO. LTD.

5 Wates Way, Brentwood, Essex CM15 9TB, United Kingdom 


\title{
Diagenetic factors controlling reservoir quality in the Faraghan Formation (Lower Permian), Darang Field, Southern Iran
}

\author{
Seyed Mohammad Zamanzadeh ${ }^{*}$, Saeid Mirzaei², Mehrdad Sardar Abadi²,3 \\ and Mohammad Poosti ${ }^{4}$ \\ ${ }^{1}$ Faculty of Geography, University of Tehran, Tehran, Iran \\ ${ }^{2}$ Petroleum Geology Research Group, Iranian Academic Center for Education, Culture and \\ Reasearch (ACECR), Iran \\ ${ }^{3}$ Pe'trologie se'dimentaire, B20, Universite' de Lie`ge, Sart Tilman, 4000 Lie`ge, Belgium \\ ${ }^{4}$ Geology Department, Faculty of Science, Hormozgan University, Iran \\ *Author for corresponding. E-mail: smzamanzadeh@gmail.com
}

(Received 23 November 2010; accepted 10 March 2011)

\begin{abstract}
The role of diagenesis in affecting (reduction or enhancement) reservoir quality in the Faraghan Formation in Darang \#1 well was investigated. The Faraghan Formation is mainly composed of sandstone facies along with minor mudstone and siltstone and grades upward into mixed carbonate -siliciclastic facies and then to Dalan Formation carbonates. Depositional environment of this formation comprises various sub-environments of a delta setting in the lower part of the formation which grades upward into a shallow marine clastic environment in the upper part. The processes enhancing reservoir quality include dissolution of carbonate grains and cements and alteration of feldspar grains. Burial history diagram shows that after deposition during Lower Permain, the formation underwent a rapid burial up to 1000 meters below sea level in Upper Permian. Then a slight uplift (about 100 meters) and gradual burial followed up to MidJurassic. Afterwards the formation experienced a series of rapid and moderate uplift from Mid-Jurassic to Tertiary when the formation uplifted to around 2500 meters above sea level. The suitable conditions resulting in dissolution took place in shallow buried sandstones. These conditions occurred two times during burial history: at the early stages of eodiagenesis and during telodiagenesis. The major processes deteriorating reservoir quality include compaction and cementation. Major cement types include carbonate cements (dolomite, siderite), clay cements (kaolinite, sericite, chlorite), silica cement and pyrite cement. The most abundant cement is the carbonate cement especially dolomite. The dolomite cement occurs as intergranular and poikilotopic forms. The most frequent clay cement is sericite which dominates in sitstones and lithicarenites. Silica cement, where present, fills all the pore spaces. The least frequent cement
\end{abstract}


type is pyrite which is found in two forms of poikilotopic and framboidal. Where it is found in the form of poikilotopic cement, it massively fills the pore spaces and deteriorates the porosity and permeability of the sandstones.

Keywords: Diagenesis, Reservoir quality, Faraghan Formation, Zagros Basin, Lower Permian

\section{INTRODUCTION}

Diagenetic processes significantly affect porosity and permeability and hence reservoir quality (Wilson, 1994; Primmer et al., 1997; Molenaar, 1998; Jeans, 2000; Burley and Worden, 2003; Gao et al., 2009). Although the relationship between diagenesis and reservoir quality is vastly investigated and documented (Reed et al., 2005), the major factors influencing diagenesis are not completely understood and diagenetic alterations in reservoir properties remain largely unpredictable (Molenaar, 1998). Since diversity of diagenetic processes and products is very high in clastic sediments especially sandstones, the major goal in diagenetic research and surely the most practical application, includes predicting the occurrence and amount of authigenetic mineral assemblages in sandstones of a given burial history (Worden and Burley, 2003). The distribution of diagenetic products (especially cements) in oilfields is critical to the spatial variation of porosity and permeability, and hence plays the key role in setting up a reservoir model (Burley and Worden, 2003).

Faraghan Formation (Lower Permain) in Zagros is a clastic unit underlying immediately below Dalan (Khuff) Formation (Upper Permian) and is the lowest unit in Dehram Group (Permo-Traissic) which hosts huge amount of gas accumulations (Bordenave, 2008). This formation is time-equivalent of Unayzah, Garif and AlKhalata Formations in Saudi Arabia and other countries in the southern Persian Gulf. The Unayzh Formation is reported as oil and gas reservoir especially in Saudi Arabia and Oman as well as other Arabian countries mentioned above (Konert et al., 2001). The Faraghan Formation as the most low-lying formation in the Dehram Group in the Zagros has recently come into the center of attention from exploration point of view, so that several exploration programs are set up to evaluate this formation in the Persian Gulf region.

In this paper we are going to discuss the role of diagenetic products and their timing in affecting reservoir quality of the Faraghan Formation in Darang\#1 well located in Coastal Fars region in the Zagros area.

\section{GEOLOGICAL AND STRATIGRAPHIC LOCATION}

Darang \#1 well was drilled in the northern flank of Darang structure in Coastal Fars area in 1977 (NIOC Exploration Directorate internal reports). Tectonically speaking, this field is situated in Zagros Folded Thrust Belt (Alavi, 2004) which is one of the most proliferous zones from hydrocarbon exploration and production point of view (Bordenave, 2008). The Zagros fold-thrust belt (ZFTB) forms the less strained external part of the orogen and forms a set of folded and faulted rocks composed of 4 to 7 kilometers of mainly Paleozoic and Mesozoic successions overlain by 3 to 5 
kilometers of Cenozoic siliciclastic and carbonate rocks (Alavi, 2004). This complex is located on highly metamorphosed Proterozoic Pan-African basement that was affected by the late Neoproterozoic-Cambrian Najd strike-slip faults (Brown and Jackson, 1960; Moore, 1979; Agar, 1987; Husseini, 1988). The southwestern boundary of the Zagros fold-thrust belt defines the present-day Zagros deformational front (ZDF), to the southwest of which deformation has not yet propagated (Alavi, 2004).

Darang structure is located in the south-east of Mond, in the west of Kangan and north-east of North Pars structures in $51^{\circ}, 37^{\prime}, 11.2^{\prime \prime}$ longitude and $28^{\circ}, 7^{\prime}, 3.95^{\prime \prime}$ latitude (Fig. 1). Mond, Kangan and North Pars structures are all known as gas fields in the south of Iran. Darang\#1 is the deepest exploration well drilled in Coastal Fars area and represents the most comprehensive subsurface geological information about Paleozoic succession of the Zagros Basin. The identified Infracambrian formation is Hormoz (?) salts and the Paleozoic formations in this well are Mila (Cambrian), Ilbeyk and Zard Kuh (Ordovician), Sarchahan (Silurian), Zakeen (Devonian), Faraghan and Dalan (Permian) Formations. Lower Paleozoic succession mainly encompasses Devoanian Zakeen Formation which is mainly composed of medium to fine grained sandstones; Silurian Sarchahan Formation which is composed mainly of shale and mudstone along with minor thin sandstone beds; Ordovician Ilbeyk and Zard Kuh Formations which are composed of sandstone, shale and siltstone along with thin beds of limestone and dolomite in and Middle-Upper Cambrian Mila Formation which is composed of evaporites and limestone beds (Gavidel-Syooki, 1990). In Darang\#1 the Faraghan Formation is mainly composed of fine-medium grained sandstones and various types of mixed siliciclastic and carbonate sandstones and carbonate and clastic mudstones especially in the upper parts of the formation. The reported thickness for this formation is about 350 meters. The Faraghan Formation unconformably overlies on Silurian-Devonian clastics (Fig. 1) and grades upward into carbonates of the Dalan Formation (Ghavidel-Syooki, 1990).
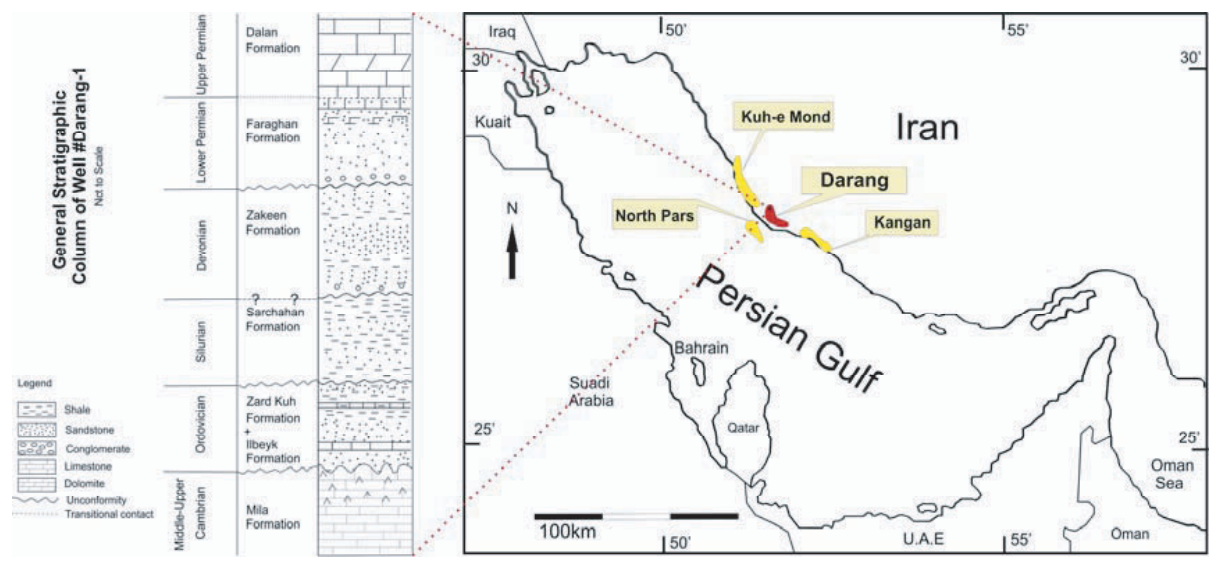

Figure 1. Location map and general stratigraphic column in Darang\#1 well. 


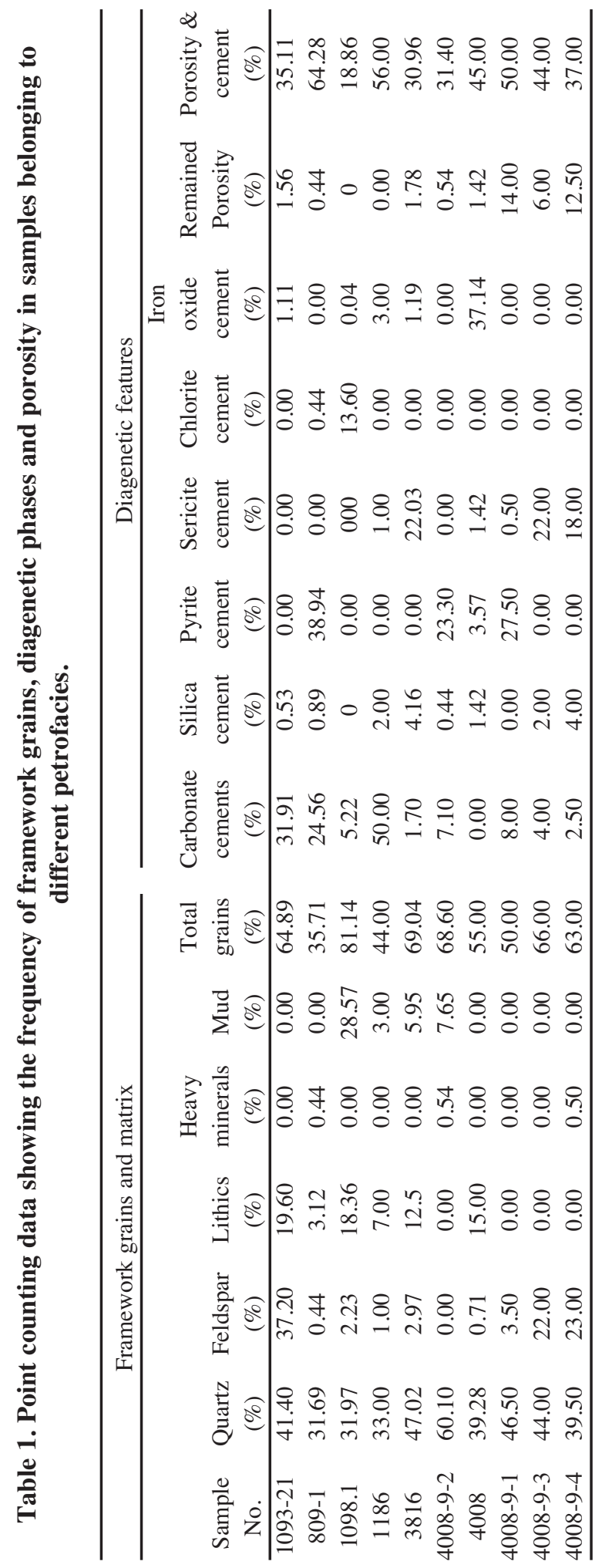


Sedimentation of the Faraghan Formation took place in a delta to shallow marine sedimentary environment which gradually changed into a shallow carbonate shelf in which sedimentation of the Dalan Formation took place (Zamanzadeh, 2008; Zamanzadeh et al., 2009; 2010).

\section{MATERIALS AND METHODS}

In this research 370 thin sections, which were prepared from cuttings, were studied to determine petrofacies and diagenetic phases. Frequency of framework grains was identified through using comparison charts (Folk et al., 1970) and a point counting was also carried out to quantify volume of frame work grains and diagenetic phases (Table 1). Petrofacies nomenclature was according to Pettijohn et al. (1987) and Zuffa et al. (1994). Petrographic techniques were used for petrofacies analysis of the rocks and investigating the diagenetic products and their relationships. In this regard, 5 petrofacies were determined and described (Table 2).

Table 2. Identified petrofacies in Faraghan Formation in Darang well\#1.

\begin{tabular}{cl}
\hline \multicolumn{1}{c}{ Petrofacies } & \multicolumn{1}{c}{ Characteristics } \\
\hline Lithicarenite (LA) & $\begin{array}{l}\text { Medium to fine grained mature sandstone. It is composed of quartz, } \\
\text { feldspar (mainly plagioclase), zircon, micas, tourmaline, volcanic } \\
\text { lithics and chert grains. The dominant cements are poikilotopic } \\
\text { dolomite and siderite but pyrite, sericite and rarely chlorite is seen } \\
\text { too. Occasionally, there are some beds composed solely of quartz, } \\
\text { muscovite, biotite and chlorite } \\
\text { Medium to fine grained mature sandstone mainly composed of } \\
\text { Quartzarenite (QA) } \\
\text { are found. The dominant cements are poikilotopic dolomite and } \\
\text { pyrite. Occasionally silica overgrowth as syntaxial rims around } \\
\text { quartz grains is observed } \\
\text { Fine to very fine immature sandstone with over 15\% carbonate and } \\
\text { clastic mud matrix. Major grains are quartz and minor ones are zircon, } \\
\text { feldspar and volcanic lithics. Very rarely framboidal pyrite is observed } \\
\text { These sandstones are composed of both clastics (mainly quartz) and } \\
\text { carbonate components mainly carbonate mud which was later } \\
\text { partially recrystallized into calcite spars. The other carbonate } \\
\text { components include ooids, peloids, fossil fragments such echinoids } \\
\text { and bivalves and saddle dolomite as cement. Rarely anhydrite } \\
\text { nodules are observed. This petrofacies is only observed in the upper } \\
\text { part of the formation } \\
\text { Silt and clay sized grains which are sometimes observed in separate } \\
\text { laminas. Pyritization is usually seen as framboidal pyrite in clay } \\
\text { dominant laminas and massive pyrite in silt dominant ones. Later } \\
\text { oxidation of pyrite is resulted in goethite development and dying the } \\
\text { grains red. Sometimes bioturbation is observed }\end{array}$ \\
&
\end{tabular}


Table 3. Identified facies and depositional environment of the Faraghan Formation in Darang well\#1.

\begin{tabular}{|c|c|c|c|}
\hline Facies & Petrofacies & $\begin{array}{l}\text { Log } \\
\text { response }\end{array}$ & Depositional environment \& characteristics \\
\hline 1 & $\begin{array}{c}\text { LA, } \\
\text { volcanic } \\
\text { lithics } \\
\text { dominated }\end{array}$ & blocky & $\begin{array}{l}\text { Abundant volcanic lithics and low mineralogical maturity } \\
\text { illustrate rapid deposition not far from source area. } \\
\text { Development of poikilotopic cement on carbonate grains } \\
\text { or mud during burial expresses severe changes in primary } \\
\text { components. Combination of blocky log response with } \\
\text { petrographic evidence indicate an interfluve depositional } \\
\text { environment }\end{array}$ \\
\hline 2 & LA & $\begin{array}{l}\text { Bell- } \\
\text { shaped }\end{array}$ & $\begin{array}{l}\text { This facies comprises a fining-upward sequence starting } \\
\text { with medium grained and ending in very fine grained } \\
\text { sandstone. This fining -upward sequence is illustrated in } \\
\text { bell-shaped log response. Framboidal pyrite indicated the } \\
\text { development of reducing and nearly organic rich } \\
\text { environment near the top. Combination of petrographic and } \\
\text { log evidence indicate sedimentation in an abandoned } \\
\text { channel environment }\end{array}$ \\
\hline 3 & LA & $\begin{array}{l}\text { Funnel- } \\
\text { shaped }\end{array}$ & $\begin{array}{l}\text { This facies comprises a coarsening-upward sequence } \\
\text { starting with fine to very fine grained and ending in medium } \\
\text { grained lithicarenites. Increasing grain size upwards indicate } \\
\text { an increase in energy of the environment and is reflected in } \\
\text { log response too. Petrographic and log evidence indicate } \\
\text { sedimentation in a shallowing upward progressive delta } \\
\text { environment }\end{array}$ \\
\hline 4 & QA & $\begin{array}{l}\text { Funnel- } \\
\text { shaped }\end{array}$ & $\begin{array}{l}\text { This facies is composed of very fine grained well sorted } \\
\text { quartz arenites with an increase in size upward, indicated in } \\
\text { the funnel shape of the log. Abundance of well sorted quartz } \\
\text { grains illustrates the dominance of high energy environment, } \\
\text { which was a delta front high energy environment }\end{array}$ \\
\hline 5 & QA & Blocky- & $\begin{array}{l}\text { This facies is composed of very fine grained well sorted } \\
\text { quartzarenites increasing in size upward. Development of } \\
\text { well sorted quartz arenites indicates a very high energy } \\
\text { environment. Petrographic evidence combined with blocky } \\
\text { log response indicates sedimentation in a shoreline } \\
\text { environment attached to a delta. Great thickness of this unit } \\
\text { in the upper part of the formation shows stability of the } \\
\text { environment for much longer time }\end{array}$ \\
\hline 6 & $\begin{array}{l}\text { Md, } \\
\text { HA, } \\
\text { QW }\end{array}$ & $\begin{array}{l}\text { Funnel- } \\
\text { shaped }\end{array}$ & $\begin{array}{l}\text { This facies starts with quartz wacke and with a decrease in } \\
\text { grains size and ends in mudstones in the upper part. This is } \\
\text { reflected in the funnel-shaped log response. In the upper part } \\
\text { of the formation instead of mudstone, sandy and silty } \\
\text { carbonate mudstone develop. Accordingly, this facies is } \\
\text { developed in a pro-delta environment which shows a fall in } \\
\text { sea-level or delta progradation or both upwards }\end{array}$ \\
\hline
\end{tabular}


Since the logging in this well was carried out long time ago and therefore they were analogue so the curves were first digitized and then plotted by LogPlot 7 . Due to the lack of cores, the interpretation of sedimentary environment was mainly based on the combination of petrofacies and gamma ray logs association. Description of facies and their characteristics are summarized in Table 3. In this study, classification of diagenetic products into 'eodiagenetic' and 'mesodiagenetic' follows Morad et al. (2000).

\section{DISCUSSION}

\subsection{Sedimentary environment}

Petrography study of cuttings in Darang\#1 illustrates that the Faraghan Formation is totally composed of five petrofacies including quartz arenites, lithic arenites, quartz wacke, hybrid arenite and siltstone/mudstone (Table 2). Fine grained quartz arenites and volcanic lithic bearing lithic arenites totally comprise $90 \%$ of the studied succession of this formation. To reconstruct the sedimentary environment of the formation, gamma ray logs and petrofacies analysis of the formation were combined so that sedimentary facies were defined accordingly (Zamanzadeh et al., 2010).

In this regard totally six sedimentary facies were introduced in the Faraghan Formation in Darang\#1 (Table 3). These facies represent that sedimentation of the formation took place in various subenvironments of a delta setting in the lower part of the formation which grades upward into a shallow marine clastic environment in the upper part (Figs. 2 and 3) and then gradually this shallow marine clastic shelf grades upward into a carbonate shelf (Dalan Formation) (Zamanzadeh et al., 2010).

\subsection{Diagenetic processes and products}

Diagenetic processes observed in the Faraghan Formation in Darang\#1 include compaction, cementation, feldspar alteration and quartz dissolution which are discussed in detail below.

\section{Cementation}

This process plays the major role in porosity reduction in the Faraghan Formation sandstones. The cements include carbonate (dolomite and siderite), pyrite, chlorite, silica, iron oxide and feldspar overgrowth.

\section{Carbonate cements}

Carbonate cements are abundantly observed in sandstones and siltstones. Dolomite and siderite cements fill $10-30 \%$ and $1-2 \%$ of rock volume, respectively. Dolomite cements usually are observed in two forms: smaller intergranular dolomite crystals (50-100 microns) which usually show dissolution evidence and larger crystals of poikilotopic form (Figs. 4 and 8). Siderite cement occurs as intergranular usually anhedral and occasionally euhedral cement (Fig. 4). In the absence of smaller dolomite cements, poikilotopic dolomite cement (200-400 microns) is the first cement lying on the grains. In this situation the poikilotopic cement usually encompasses at least three or four grains on which corrosion is observed (Fig. 4). Sometimes it seems that poikilotopic dolomite cement is the result of recrystallization of carbonate mud which is evidently finer crystalline in some parts (Fig. 4). It appears that the growth and coalescence of the mud grains took place during later burial and resulted in poikilotopic dolomite cement. This kind of cement is observed almost in all 


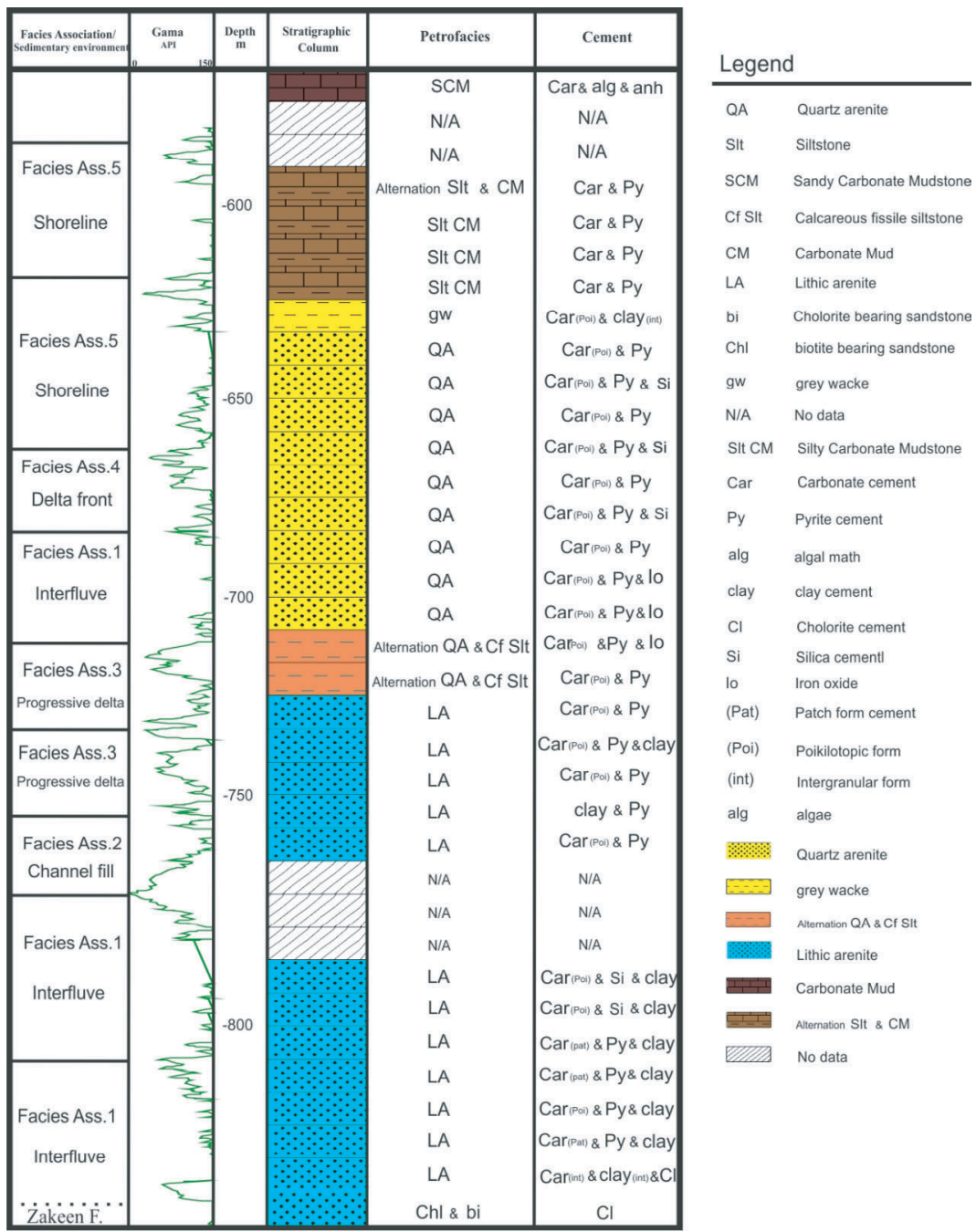

Figure 2. Stratigraphic column, gamma ray log signature, comprising lithofacies and observed major cements along with the inferred sedimentary subenvironments in Darang\#1 well.

petrofacies but it is most frequent in lithicarenites. Since carbonate cement with smaller crystal size is the first diagenetic phase lying immediately on the grains, it is considered as the first carbonate cement formed in eodiagenesis stage compared with the larger poikilotopic cement which was formed in later stage (mesodiagenesis). Dissolutional notches on the smaller dolomites are later filled with sericite cement (Figs. 8 and 11).

Siderite cements are very less frequent and small in size (100-200 microns) and develop just as intergranular cement filling porosity as patches of siderite. This 


\section{Sedimentary Environment Model for \\ Darang\#1 well}
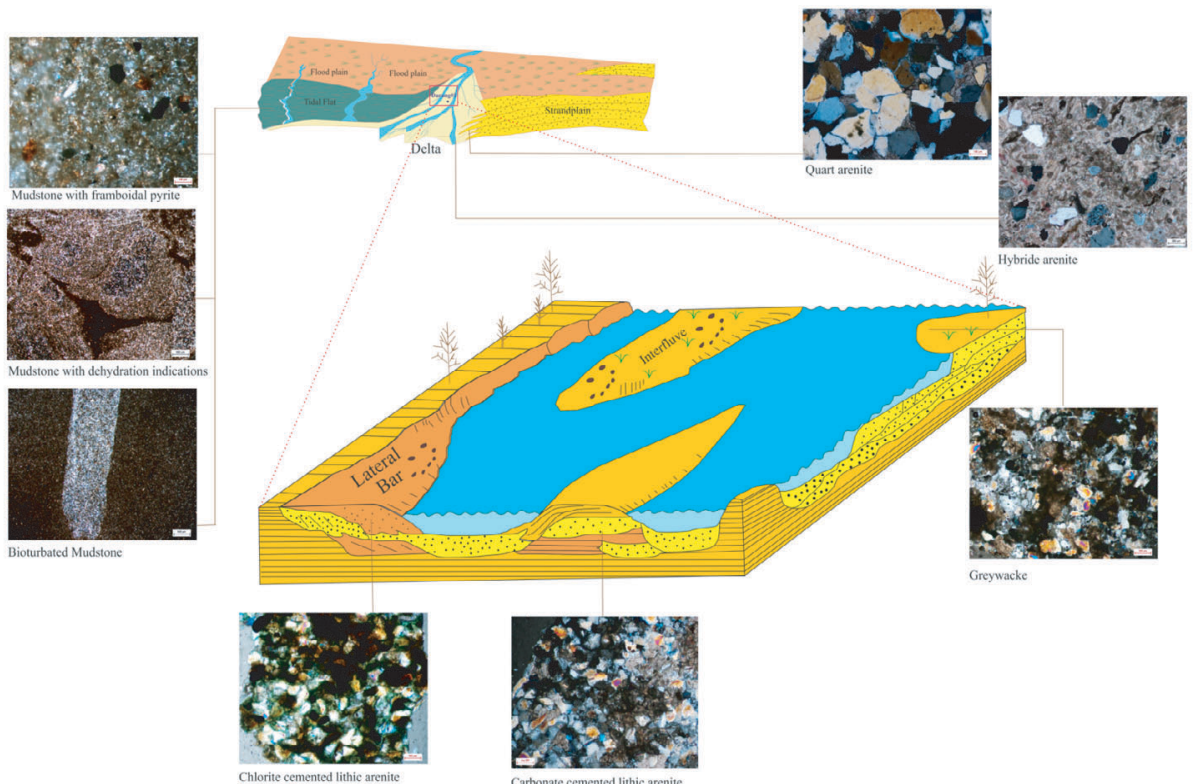

Figure 3. Reconstruction of Faraghan Formation sedimentary environment and its subenvironments along with their typical petrofacies.
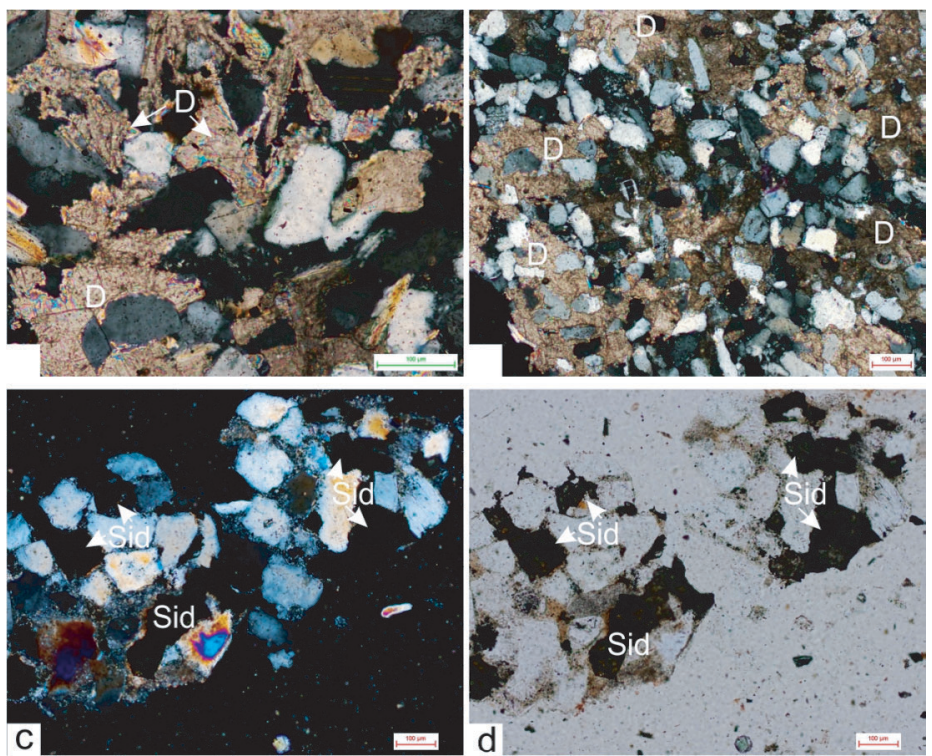

Figure 4. Carbonate cements: poikilotopic dolomite (D) cement (a and b), crossed polars view, depth: $-640 \mathrm{~m}$; patches of siderite (Sid) cement, crossed polars (c) and plain poloarized (d) view, (depth: $-842 \mathrm{~m}$ and $-730 \mathrm{~m}$ respectively). 
cement almost entirely occurs in quartz arenite petrofacies and not seen in others. According to their frequency and abundance, carbonate cements, especially poikilotopic dolomite cement, are the most important diagenetic products reducing the porosity.

\section{Pyrite cement}

This cement is one of the major cements in sandstones especially quartz arenite petrofacies (Fig. 5). This cement is observed in two forms: framboidal and poikilotopic in both mudstones and sandstones respectively. The poikilotopic form of pyrite cement is very large crystalline and had a major role in severe porosity reduction especially in sandstones of good reservoir quality; however it is not found very frequently (Fig. 5). This type of pyrite is always observed growing on the dolomite cement crystals indicating its formation after dolomite cement. It completely fills all the voids and is sub-anhedral in shape.

Framboidal pyrite is an eogenetic product which is resulted from microbial activity in which the resulted $\mathrm{H}_{2} \mathrm{~S}$ initiated pyritization in organic matter bearing mudstones (Vieira and Ros, 2007; Sun et al., 2010). The massive poikilotopic pyrite cement is a mesogenetic cement which is attributed to the reduction of iron oxides present in the sediments (hematite) in the presence of hydrocarbons (Elmore et al., 1987) especially gas in this case.

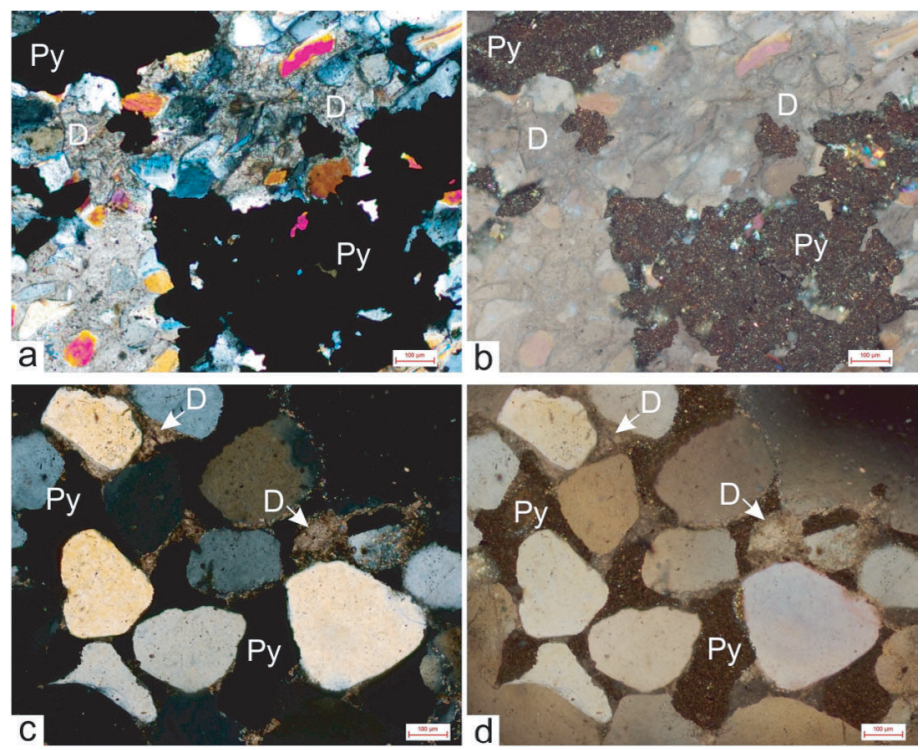

Figure 5. a) poikilotopic pyrite (Py) cement filling the secondary porosity resulted from dolomite (D) dissolution, crossed polars view, depth: $-760 \mathrm{~m}, \mathrm{~b}$ ) the same photo in reflective light and crossed polarized view; c) growth of pyrite cement over dolomite cement filling the center of pores, crossed polars view, depth:-700 m; d) the same photo in plain polarized view. 

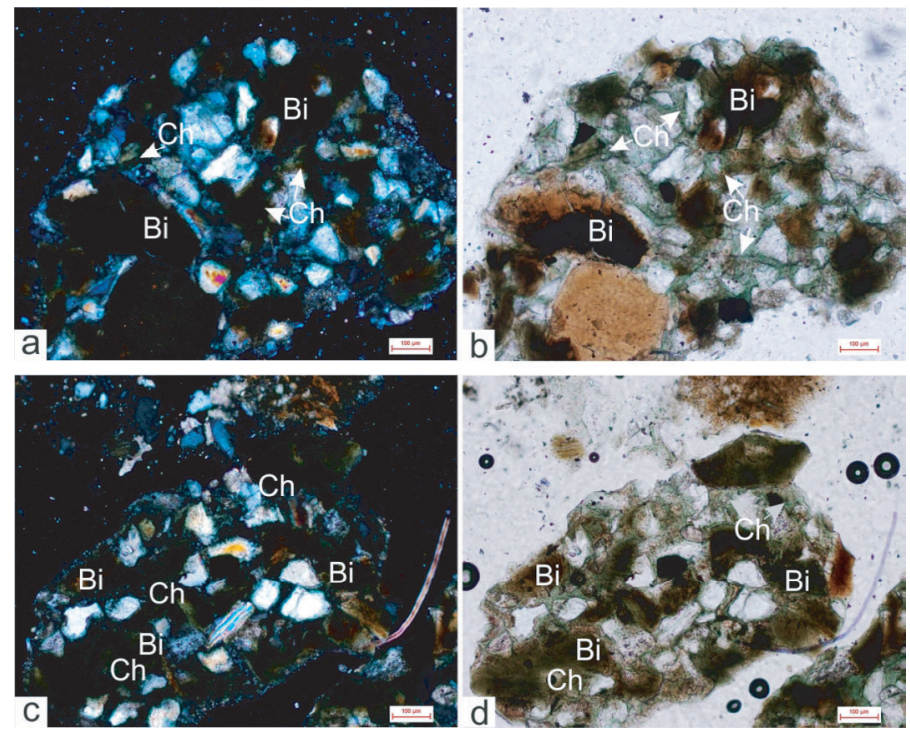

Figure 6. a) development of chlorite cement $(\mathrm{Ch})$ due to the biotite (Bi) alteration, crossed polars view, depth: $-848 \mathrm{~m}$; b) the same photo in plain polarized view; c) chlorite cement filling all the por spaces in fine sandstones, crossed polars view, depth $-840 \mathrm{~m}$. The same photo in plain polarized view.

\section{Chlorite cement}

Chlorite cement, when present, almost completely fills intergranular porosity. The chlorite crystals occur as very minute crystals (c. 5-10 microns) lying immediately on the grains. In sandstones with chlorite cement there is no evidence and remains of other diagenetic minerals. This cement is observed in lithicarenites rich in biotite grains and fills the void spaces (Fig. 6). Biotite alteration is considered as the main mechanism of chlorite cementation in these sandstones (Horne, 1968) according to the following:

$$
\underset{\text { Biotite }}{\mathrm{K}(\mathrm{Mg}, \mathrm{Fe})_{3}}\left(\mathrm{AlSi}_{3} \mathrm{O}_{10}\right)(\mathrm{OH})_{2} \rightarrow(\mathrm{Mg}, \mathrm{Fe})_{3}(\mathrm{Si}, \mathrm{Al})_{4} \mathrm{O}_{10}(\mathrm{OH})_{2} \cdot \underset{\text { Chlorite }}{(\mathrm{Mg}, \mathrm{Fe})_{3}(\mathrm{OH})_{6}}
$$

Since it is observed that chlorite cement forms in temperatures 90 to 120 degrees centigrade (Aagaard et al., 2000), it can be assumed that development of chlorite cement took place in deep burial environments (around 3-4 kilometers of burial). On the other hand, this can mean that chlorite cement in the sandstones filled the remained porosity which was not occupied by any other diagenetic mineral before.

\section{Silica cement}

This cement usually occurs as synatxial overgrowth on quartz grains with an average size of 100 to 150 microns. This cement is mainly observed in quartz arenite and lithicarenites in which the pressure dissolution is a common phenomenon (Fig. 7). 

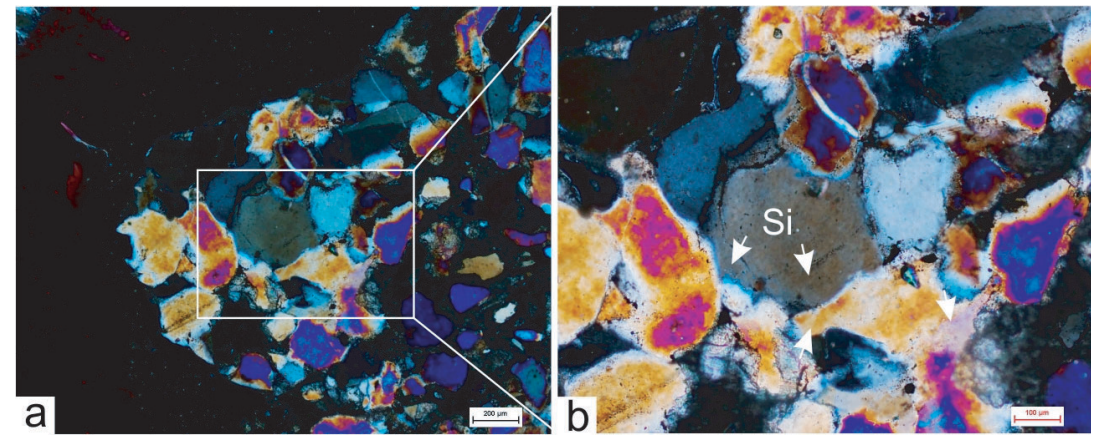

Figure 7. Silica cement (Si) as overgrowth filling all the pores, crossed polars, Depth: $-645 \mathrm{~m}$.

Most of time there is an iron oxide staining between the quartz grains and silica cement lying on the grain (Fig. 7). This can indicate a later development of silica cement after a long period of subaerial exposure. This can be most probably during deeper burial conditions since the grains show concave-convex boundary which indicates a period of severe compaction before silica cement filled the remained pore spaces between grains (Fig. 7). Silica cement is the major cement playing an important role in porosity reduction in sandstones. This cement fills $20-50 \%$ of voids in quartz arenites and lithicarenites.

\section{Sericite cement}

This cement is very abundant in lithicarenite petrofacies as very minute and delicate flakes with yellow to golden color in crossed polars filling some or whole part of porosity (Fig. 8). This cement is very abundantly found where feldspar grains are obviously present and in this situation it is easily seen that alteration of feldspar in the rims occurred and sericite cement is developed at the same place (Fig. 8). Where

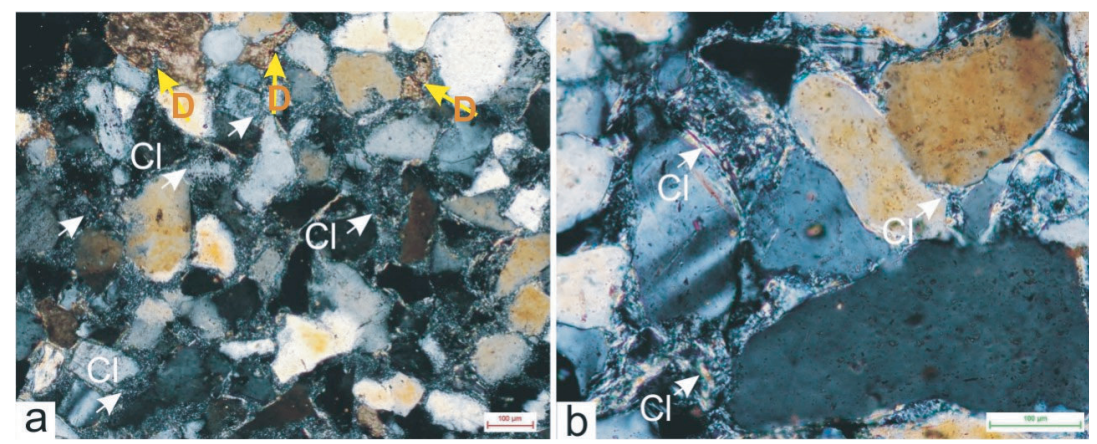

Figure 8. a and b) sericite cements $(\mathrm{Cl})$ almost completely filling the pore spaces in sandstones, dissolution of early stage (eodiagenesis) carbonate cement (D) and later development of sericite cement is shown with arrows; alteration of feldspar and development of sericite is evident in (b), crossed polars, depth: $-822 \mathrm{~m}$. 
present, sericite cement encompasses almost all grains like a rim (Fig. 8). Sericite cement fills between $20-50 \%$ of pore spaces in the mentioned petrofacies. This cement usually coats the grains or fills all the pore spaces completely. In the former it is the first cement immediately lying on the grains. The resulted sericite cement significantly reduced porosity of the petrofacies. Sometimes the sericite cement fills the enhanced porosity due to carbonate cement dissolution (Figs. 8 and 11). In this situation the carbonate cement which immediately lies on the grains show dissolutional notches which are filled with later stage sericite cement (Figs. 8 and 11).

\section{Iron oxide cement}

This cement is observed in all recognized petrofacies including sandstones and mudstones in Darang\#1. Occurrence of this cement is closely related to pyrite formation especially the framboidal form, so that subsequent alteration of framboidal pyrite especially in mudstones has caused iron oxide cement development (Fig. 9).
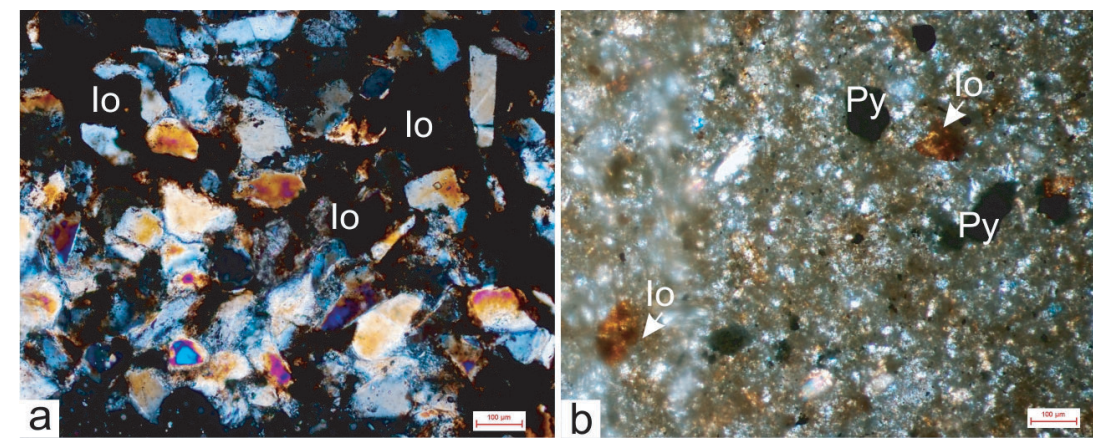

Figure 9. a) iron oxide (Io) cement filling almost all the pores, crossed polars; depth: $-690 \mathrm{~m}, \mathrm{~b}$ ) iron oxide cement which is produced as a result of framboidal pyrite alteration, plain polarized; depth: $-720 \mathrm{~m}$.

\section{Compaction}

Compaction is caused by overlying strata. In this process overburden pressure results in closer packing of grains, expelling intergranular fluids and consequently porosity reduction (Kim and Lee, 2004; Lou et al., 2006). The higher the overburden, the intense is the compaction. This process is observed in both physical and chemical form in the Faraghan Formation.

As a result of compaction in grain supported petrofacies such as quartz arenites and lithicarenites, pressure dissolution is developed (Fig. 10). The latter process resulted in silica overgrowth cement, concave-convex contact of grains, silica dissolution and later precipitation on quartz grains as syntaxial cement. These processes usually occur in mesogenetic environments (Burley and Worden, 2003). In some sandstone petrofacies, carbonate cement is developed in the form of patches (Fig. 10) mainly due to disintegration of carbonate lithics as a result of compaction and producing pseudomatrix. Then during burial, patchy large crystals of carbonate cement (mainly dolomite) formed mainly due to the neomorphism of carbonate mud. 

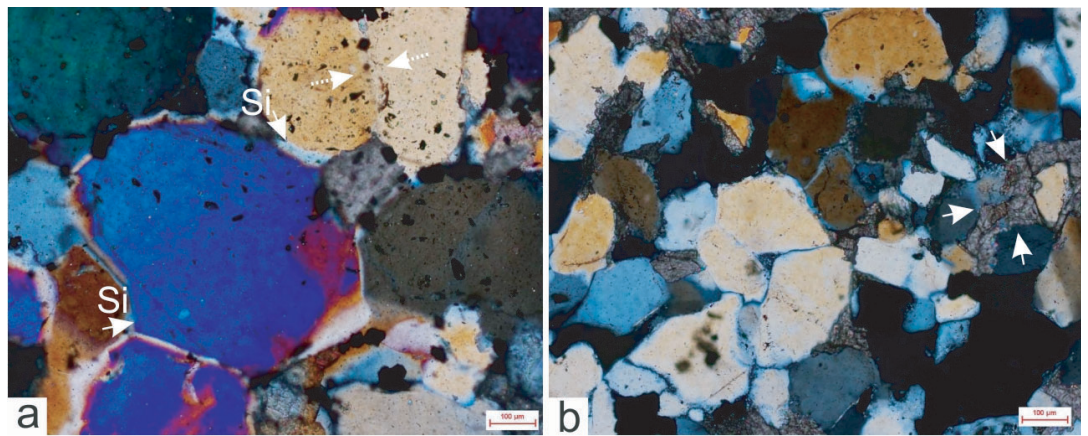

Figure 10. a) compaction resulted in concave-convex contacts and quartz overgrowth (arrows), crossed polars; depth: $-672 \mathrm{~m}$; b) disintegrated carbonate lithic fragments (arrows) which later recrystalized into dolomite cement, crossed polars; depth:-642 m.

\section{Feldspar alteration}

Feldspar alteration is mainly observed in petrofacies rich in feldspar grains (Fig. 11). This process is generally related to perculation of undersaturated meteoric waters in shallow parts of the basin (Ketzer et al., 2005). The latter process causes feldspar alteration and consequently kaolinite cement development (Lanson et al., 2002). Later in mesogenetic environment, kaolinite cement altered to dickite or illite cements (Tang et al., 1997; Zamanzadeh et al., 2009). From reservoir quality point of view, feldspar alteration increases porosity first, but later clay mineral cement development causes in porosity and permeability reduction. Since feldspar alteration takes place due to the meteoric water influx during shallow burial, i.e. eodiagenesis and telodiagenesis stages (c.f. Bjorlykke et al., 1986; Ehrenberg and Nadeau, 1989), flushing meteoric water can also be considered as an indicator of vast carbonate cement dissolution (Figs. 8 and 11) in the Faraghan Formation. The dissolutional voids later are filled with sericite cement which is the product of feldspar alteration (Fig. 11).

\section{Burial history}

Burial history diagram of the Faraghan Formation in Darang well\#1 illustrates complex downward and upward movements. Since deposition in Lower Permian the formation experienced a very slight burial (c. 100 meters) up to the Upper Permian when it started a very rapid burial to about 800 meters below mean sea level, meanwhile deposition of Dalan Formation (Upper Permian) took place (Fig. 12). Around 250 million years ago the formation underwent a slight uplift first and then a very slight burial up to Mid-Jurassic time. Since Mid-Jurassic the formation first experienced a rapid uplift followed by a very short period of stability then a series of moderate and very quick uplifts occurred up to Tertiary. The last uplift placed the formation around 2300 meters above mean sea level (Fig. 12).

\section{PARAGENESIS}

Diagenetic processes in Darang\#1 occurred during different stages of diagenesis including eodiagenesis, mesodiagenesis and telodiagenesis. These processes are 


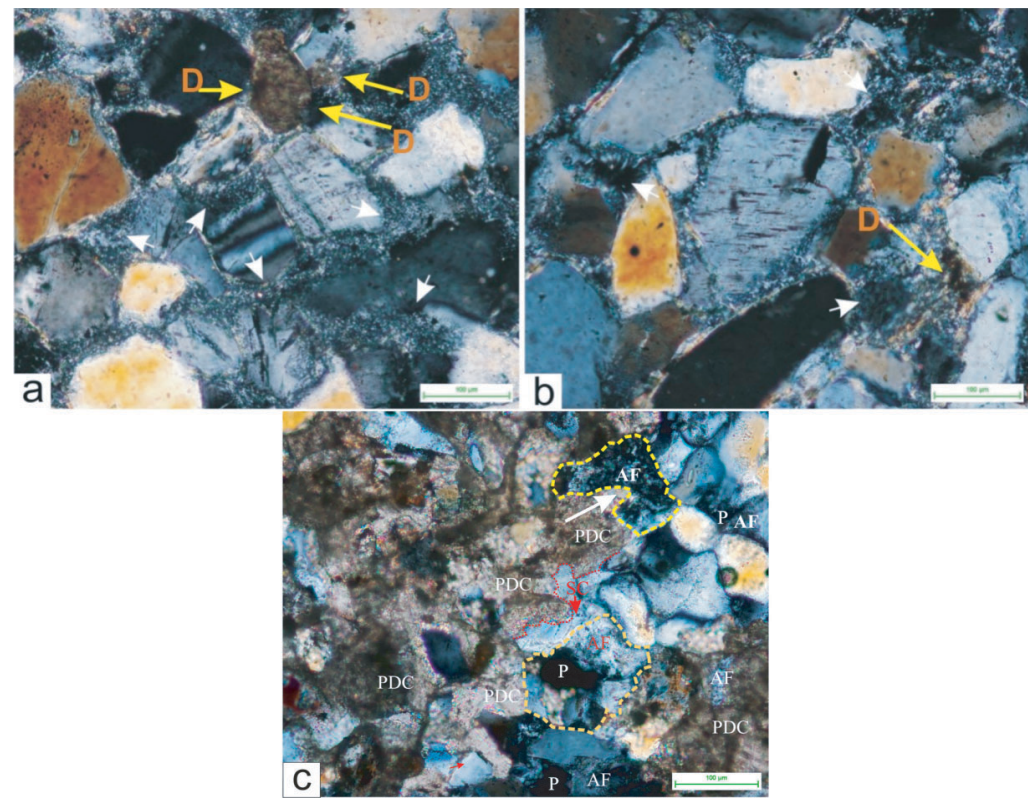

Figure 11. a) feldspar alteration starting from the margins of the feldspar grains (arrows), crossed polars; depth: $-832 \mathrm{~m}$; b) alteration of feldspar grains completely destroyed the feldspar (the lower arrow) and resulted in clay cement development (the upper arrows), crossed polars; depth:-832 m. in both (a and b) carbonate cement dissolution which was later followed with sericite cement is shown with arrows and letter D; c) alteration of feldspar (AF) produced porosity (P) and the resulted porosity later was filled with poikilotopic dolomite cement (PDC) which was intruded into the pore space (white arrow) (SC: silica cement), crossed polars; depth: $-832 \mathrm{~m}$.

summarized in Figure 12 (paragenesis). The major processes during eodiagenesis include compaction, cementation (carbonate, silica, pyrite and clay), feldspar alteration and dissolution of carbonates (grains and cements). Mesodiagenesis stage encompasses processes such as compaction, cementation (carbonate, silica, clay and carbonate) and quartz corrosion. Cementation (iron oxide, carbonate and clay), feldspar alteration and carbonate dissolution occurred during telodiagenesis.

\section{CONCLUSIONS}

The Faraghan Formation in Darang\#1 well underwent various diagenetic processes which greatly affected reservoir quality of the formation. These processes started after deposition in Permian up to uplifting of the sediments (in Tertiary). The processes affecting reservoir quality are classified into two broad categories: enhancing and reducing processes. Reducing processes include compaction and cementation. Enhancing processes encompass dissolution of carbonates (cements and grains) and feldspar alteration. The first and major process reducing reservoir quality includes 


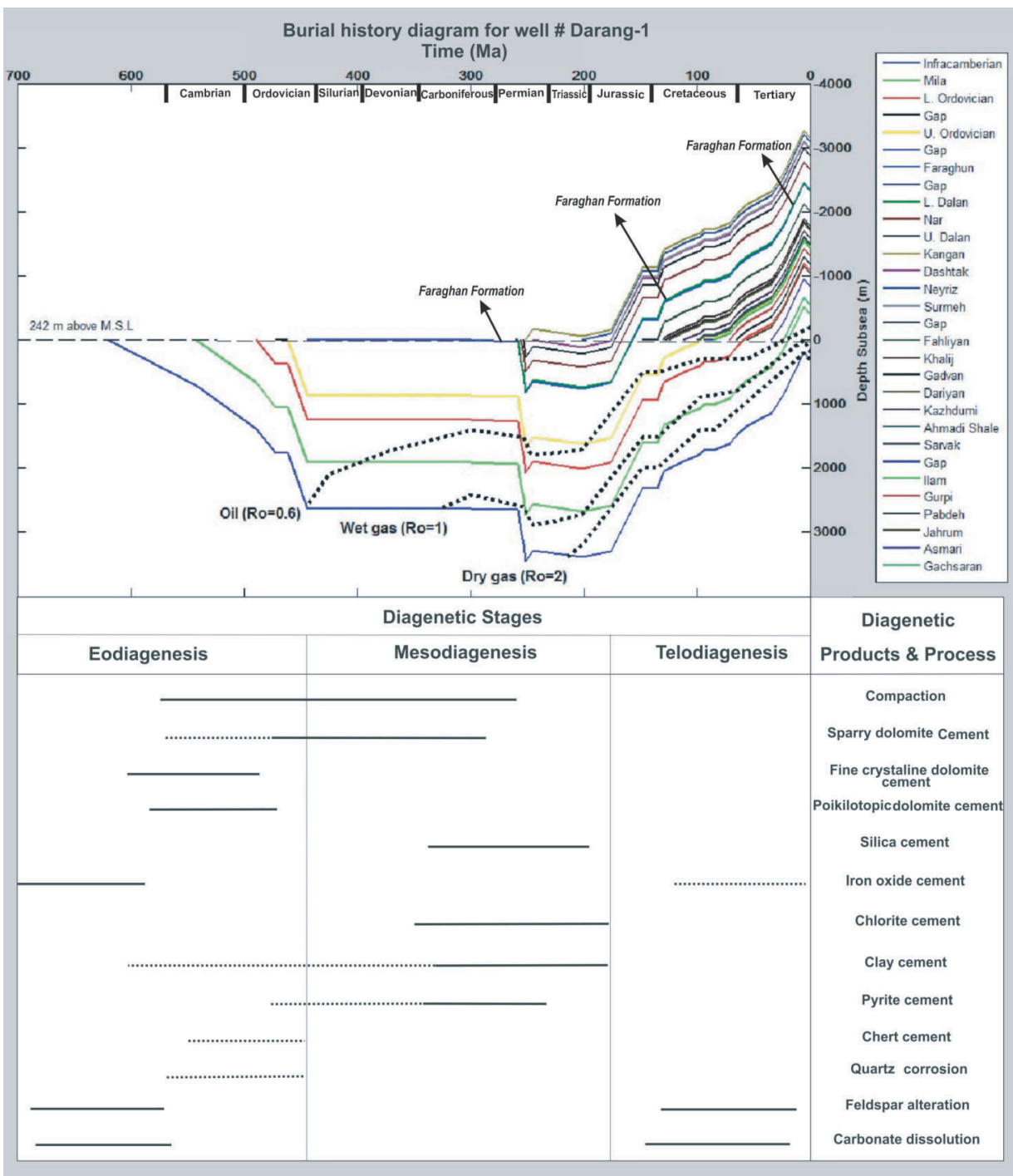

Figure 12. Burial history diagram matched with paragenesis of diagenetic products developed during eo-, meso- and telodiagenesis stages in Darang\#1.

compaction which started early after deposition and continued up to the late stages of mesodiagenesis. Late stages of compaction represented by concave-convex contacts of grains. The other process greatly affecting porosity and permeability is cementation. This process in the Faraghan formation encompasses different types of cements including pyrite cementation, carbonate (dolomite) cementation, clay mineral cementation indicated by sericite, iron oxide cementation and silica cementation. Among all cement types, pyrite, dolomite and silica are observed in all petrofacies and 
are more abundant. Iron oxide and clay cements are more petrofacies-related which occur in mudstones and feldspar rich petrofacies (i.e. subarkoses and lithicarenites) respectively. Pyrite cementation started from eodiagenesis stages as framboidal pyrite development and vastly developed in mesodiagenesis stages as blocky pyrite cement that fill all pore spaces (around 30\% of bulk volume). Silica cementation vastly occurred in mesodiagenesis stage and filled all remained pores especially in quartz arenites. Carbonate cementation started in early diagenesis stage and continued up to the late mesodiagenesis by forming large crystalline and poikilotopic crystals of dolomite. The other cement types (clays) such as chlorite and sericite are not very abundant in the Faraghan Formation sandstones.

The major enhancing process which vastly affected the reservoir quality of the sandstones is dissolution of carbonates (grains and cements). This process occurred during both early eodiagenesis and late telodiagenesis phases when meteoric water influx was significant. The latter stage dissolution had a major role in development of intervals with good reservoir quality. The other process enhancing reservoir quality was feldspar alteration which occurred during early diagenesis and late telodiagenesis under the influence of meteoric water influx. The importance of this process was not as vast as dissolution of carbonates. On the other hand, this process resulted in production of some diagenetic products such as clay cements (e.g. kaolinite) which had a role in porosity reduction.

\section{ACKNOWLEDGMENT}

We express our deep gratitude to both deputy of research and technology of Iranian ACECR (Academic Center for Education Culture and Research) and manager of research and technology of Pars Oil and Gas Company for their kind assistance and provision of facilities and necessary data. Thanks are expressed to Mohsen Ranjbaran, Ali Kadkhodaee and Vahid Tavakkoli for their useful comments in petrography studies, log and burial history diagram interpretations respectively. We would also like to thank two anonymous reviewers whose comments greatly helped in improvement of the paper.

\section{REFRENCES}

Aagaard P., Jahren J., Harstad A.D., Nilsen D. and Ramm M., 2000. Formation of grain-coating chlorite in sandstones: laboratory synthesized vs. natural occurrences. Clay Mineralogy 35, 261-264.

Agar R.A., 1987. The Najd fault system revisited: a two-way strike-slip orogen in the Saudi Arabian shield. Journal of Structural Geology 9, 41-48.

Alavi M., 2004. Regional stratigraphy of the Zagros Fold-Thrust Belt of Iran and its proforeland evolution. American Journal of Science 304, 1-20.

Bjørlykke K., Aagaard P., Dypvik H., Hastings D.S. and Harper A.S., 1986. Diagenesis and reservoir properties of Jurassic sandstones from the Haltenbanken area, offshore Mid-Norway. In: Spencer, A.M. (Ed.), Habitat of Hydrocarbons on the Norwegian Continental Shelf. Graham \& Trotman, London, pp. 275-286. 
Bordenave M.L., 2008. The origin of the Permo-Triassic gas accumulations in the Iranian Zagros foldbelt and contiguous offshore areas: A review of the Palaeozoic petroleum system. Journal of Petroleum Geology 31(1), 3-42.

Brown G.F. and Jackson R.O., 1960. The Arabian shield. 21st International Geological Congress Proceedings 9, 69-70.

Burley S.D. and Worden R.H., 2003. Sandstone diagenesis recent and ancient. Reprint series volume 4, IAS, pp.649.

Ehrenberg S.N. and Nadeau P.H., 1989. Formation of diagenetic illite in sandstones of the Garn formation, Haltenbanken area, mid-Norwegian continental shelf. Clay Minerals 24, 233-253.

Elmore R.D., Engel M.H., Crawford L., Nick K., Imbus S. and Sofer Z., 1987. Evidence for a relationship between hydrocarbon migration and authigenic magnetite. Nature 325, 428-430.

Folk R.L., Andrews P.B. and Lewis D.W., 1970. Detrital sedimentary rock classification and nomenclature for use in New Zealand. New Zealand journal of geology and geophysics 13, 937-968.

Gavidel-Syooki M., 1990. The encountered acritarchs and chitinozoan from Mila, Ilbek and Zard Kuh Formations in Tang-e-Ilbek at Zard Kuh and their correlation with the Paleozoic sequence at Chal-i-Sheh area and Darang\#1 well. Symposium on Diapirism with Special Reference to Iran 1, 140-218.

Gao C., Wang Z.L., Deng J., Zhao J.H. and Yang X.C., 2009. Physical property and origin of lowly permeable sandstone reservoirin Chang 2 division, Zhang-Han oilfield, Ordos Basin. Energy Exploration \& Exploitation 27 (5), 367-389.

Horne R.R., 1968. Authigenic prehnite, laumontite and chlorite in the Lower Cretaceous sediments of southeastern Alexander Island. British Antarctic Survey Bulletin 18, 1-10.

Husseini M.I., 1988. The Arabian Infracambrian extensional system. Tectonophysics 148, 93-103.

Jeans C.V., 2000. Mineral diagenesis and reservoir quality-the way forward: An introduction. Clay Mineralogy 35, 3-4.

Ketzer J.M., De Ross L.F., Dani and Norberto., 2005. Kaolinitic meniscus bridges as an indicator of early diagenesis in Nubian sandstone, Sinai, Egypt-discussion. Sedimentology 52, 3213-217.

Kim Y. and Lee Y.I., 2004. Diagenesis of shallow marine sandstones, the Lower Ordovician Dongjeom Formation, Korea: response to relative sea-level changes. Journal of Asian Earth Sciences 23(2), 235-245.

Konert G., Afifi A.M., Al-Hajri S.A. and Droste H.J., 2001. Paleozoic stratigraphy and hydrocarbon habitat of the Arabian plate. GeoArabia 6(3), 407-442.

Lanson B., Beaufort D., Berger G., Bauer A., Cassagnabe`re A. and Muunier A., 2002. Authigenic kaolin and illitic minerals during burial diagenesis of sandstones: A review. Clay Minerals 31, 1-22. 
Lou Z. H., Cheng J. R. and Jin A M., 2006. Origin and evolution of the hydrodynamics in sedimentary basins-A case study of the Songliao Basin. Acta Sedimentologica Sinica. 24(2), 193-201 (in Chinese).

Molenaar N., 1998. Origin of low-permeability calcite-cemented lenses in shallow marine sandstones and $\mathrm{CaCO} 3$ cementation mechanisms; an example from the Lower Jurassic Luxemburg Sandstone, Luxemburg. In Worden R.H. and Morad S. (Eds.), Carbonate Cementation in Sandstones. Special Publications of International Association of Sedimentologists 26, 193-211.

Moore J.M., 1979. Tectonics of the Najd transcurrent fault system, Saudi Arabia. Geological Society of London Journal 136, 441-454.

Morad S, Ketzer J.M. and De Ros L.F., 2000. Spatial and temporal distribution of diagenetic alterations in siliciclastic rocks: implications for mass transfer in sedimentary basins. Sedimentology 47(Suppl. 1), 95-120.

Pettijohn F.J., Seever R. and Potter P.E., 1987. Sand and Sandstone. $2^{\text {nd }}$ ed., springer Verlog - New Yourk, pp.328.

Primmer T.J., Cade C.A., Evans J., Gluyas J.G., Hopkins M.S., Oxtoby N.H., Smalley P.C., Warren E.A. and Worden R.H., 1997. Global patterns in sandstone diagenesis: their application to reservoir quality prediction for petroleum exploration. In: Kupecz, J.A., Gluyas, J. and Bloch, S. (Eds.), 1997. Reservoir Quality Prediction in Sandstones and Carbonates AAPG Memoir 69, pp. 61-77.

Reed J.S., Eriksson K.A. and Kowalewski M., 2005. Climate, depositional and burial controls on diagenesis of Appalachian Carboniferous sandstones: qualitative and quantitative methods. Sedimentary Geology 176, 225-246.

Sun Y.Z., Qin S.J., Zhao C.L. and Kalkreuth W., 2010. Experimental study of early formation processes of macerals and sulfides. Energy \& Fuels 24, 1124-1128.

Tang Z., Parnell J. and Longstaffe F.J., 1997. Diagenesis and reservoir potential of Permian-Triassic fluvial/lacustrine sandstone in the Southern Junggar Basin, Northwestern China. American Association of Petroleum Geologists Bulletin 81(11), 1843-1865.

Vieira M.M. and De Ros L.F., 2007. Cementation patterns and genetic implications of Holocene beachrocks from northeastern Brazil. Sedimentary Geology 192, 207230.

Wilson M.D., 1994. Reservoir Quality Assessment and prediction in clastic Reservoirs. SEPM Short Course 30, 432.

Worden R.H. and Burley S.D., 2003. Sandstone Diagenesis: the evolution of sand to stone. In: Burley S.D. and Worden R.H. (Eds.), Sandstone Diagenesis: Recent and Ancient, International Association of Sedimentologists Reprint Series, Blackwell Publication Ltd., 4, pp.3-46.

Zamanzadeh S.M., 2008, Sedimentary petrology/environment and sequence stratigraphy of Zakeen and Faraghan Formations in their type section (BandarAbbas area), Ph.D. thesis, University of Tehran, Iran, pp.350 (in Persian). 
Zamanzadeh S.M., Amini A. and Rahimpour-Bonab H., 2009. Eogenetic dolomite cementation in Lower Permian reservoir sandstones, southern Zagros, Iran. Geological Journal 44, 501-525.

Zamanzadeh S.M., Mirzaei S. and Sardar Abadi M., 2010. Reconstruction of sedimentary environment of Faraghan Formation in Darang\#1 well. Iranian Journal of Geology Quarterly 4(12), 93-102.

Zuffa G.G., Cabin U. and Di Giulio A., 1994. Arenite petrography in sequence stratigraphy. Journal of Geology 103, 454-459. 